Н. І. Шарикіна, А. Г. Радівосвич, М. А. Мунько, С. В. Максюта, Т. А. Бухтіарова

\title{
Сигнальний шлях Hedgehog: від механізмів трансдукції до пошуку протипухлинних засобів
}

Державна установа «Інститут фармакології та токсикології

Національної академії медичних наук України», м. Київ

Ключові слова: сигнальний шлях Hedgehog, ланки трансдукції, злоякісні новоутворення, протипухлинні засоби

У цей час накопичений значний експериментальний і клінічний матеріал щодо явищ, патогномонічних для пухлинної хвороби як основи пошуку засобів лікування хворих зі злоякісними новоутвореннями $[1,2]$.

Існує арсенал традиційних цитостатиків та їхніх комбінацій, що впливають на біосинтетичні процеси пухлинної клітини на геномному рівні. Однак цей напрям поступається пошуку таргетних (молекулярно спрямованих) препаратів, здатних переривати передачу патологічних мітогенних сигналів на геном. Ці дослідження щільно пов'язані з вивченням сигнальних шляхів нормальної та злоякісно зміненої пухлинної клітини.

Сигнальним шляхом, який передає інформацію ембріональним клітинам, необхідну для диференціації, є сигнальний шлях Hedgehog (HН). Численні дослідження показали його роль також за злоякісного росту (ембріональні пухлини мозочка, медулобластома, рак передміхурової залози, легенів, молочної залози та ін.), що викликали зацікавленість до цієї сигнальної системи як мішені для пошуку підходів до лікування раку [3-7].

Ген НН був ідентифікований понад 35 років тому під час скринінгу генів плодової мушки Drosophila melanogaster Д. Е. Вішаусом і С. Нуссейн-Вольхардом. За ці дослідження вчені отримали Нобелівську премію в 1995 році разом з генетиком Едвардом Б. Льюїсом [5]. Було показано, що втрата функціонального фенотипу НH призводила до того,

(c) Колектив авторів, 2019 що ембріони покривалися зубцями, невеликими точковими виступами, що нагадували шипучки їжака [7]. Цей сигнальний шлях одержав назву «шлях їжака».

Дослідження, спрямовані на пошук еквівалента «їжака» у хребетних, були проведені Філіпом Інгамом, Ендрю П. Макмахоном і Кліффердом Табіном. Відмічені три гомологічні гени. Два 3 них - пустельний їжак (DHH) та індійський їжак (IHH) були названі за видом їжаків, а звуковий їжак (SHH) був названий ім'ям Sonic Hedgehog (SHH), як головного героя відеогри SEGA, їжака Соніка [4, 5, 8]. Назва була розроблена Робертом Ріддлом пост- доктором лабораторії Tabin після того, як він побачив Sonic-комікс, який його дочка привезла з Англії [6, 7].

Однойменну назву 3 геном Sonic Hedgehog одержав сигнальний шлях 3 білком-лігандом, який запускає дію цього шляху (SHH) - шляху їжака. Саме Sonic Hedgehog є найвивченішим у ссавців серед 3 гомологів.

Сигнальну трансдукцію шляху $\mathrm{HH}$ у спрощеному вигляді надано на рисунку.

Основні компоненти сигнального шляху $\mathrm{HH}$ включають ліганд Sonic Hedgehog (SHH); рецептор Patched; рецептороподібний семиспіральний трансмембранний білок Smoothened (SMO), приєднаний до G-білка; 3 фактори транскрипції (GLI1, GLI2 і GLI3), названі так тому, що один з них (GLI1) асоційований 3 гліомою; негативний регулятор шляху HH - SUFU.

Ключовим для трансдукції сигналу є білок SMO, функція якого інгібується за відсутності SHH трансмембранним білком Patched. У разі зв'язування 3 ним $\mathrm{SHH}$ це інгібування знімається, що дозволяє SMO сигналізувати нижче за 
потоком і в кінцевому підсумку призводити до активації GLI - транскрипційних факторів. Активовані форми GLI впливають на гени-мішені, що кодують білки шляху HH [3-5]. SUFU перешкоджає експорту факторів транскрипції GLI через цитоплазму в ядро, їхній взаємодії 3 генами-мішенями. Важливу роль у концентруванні компонентів сигнального шляху відіграють первинні ворсинки - субклітинне продовження оболонки клітин.

Широке коло процесів, підвладних регулюючим впливам сигнального шляху НH (проліферація, міграція та інвазивна активність, епітеліальномезенхімний перехід, стовбуровість, ангіогенез, хіміорезистентність), пов'я- зані з появою низки хвороб і різних форм пухлинної хвороби відповідно на фоні інактивації шляху чи його гіперактивації. Мутації в генах PTCH1, SMO відмічені за базальноклітинної карциноми (ВСС) [9, 10], у спорадичних пухлинах людини [9, 10]. Мутації SMO мають місце в $10 \%$ спорадичних ВСС. Наявність мутацій компонентів НН-шляху доведено в разі медулобластоми, рабдоміосаркоми [11, 12] та ін.

Дослідженнями багатьох лабораторій виявлена активація шляху $\mathrm{HH}$ за різних ракових захворювань людини (лейкемії, пухлини шлунково-кишкового тракту, рак легенів, яєчників, молочної залози, простати та ін.) [6].

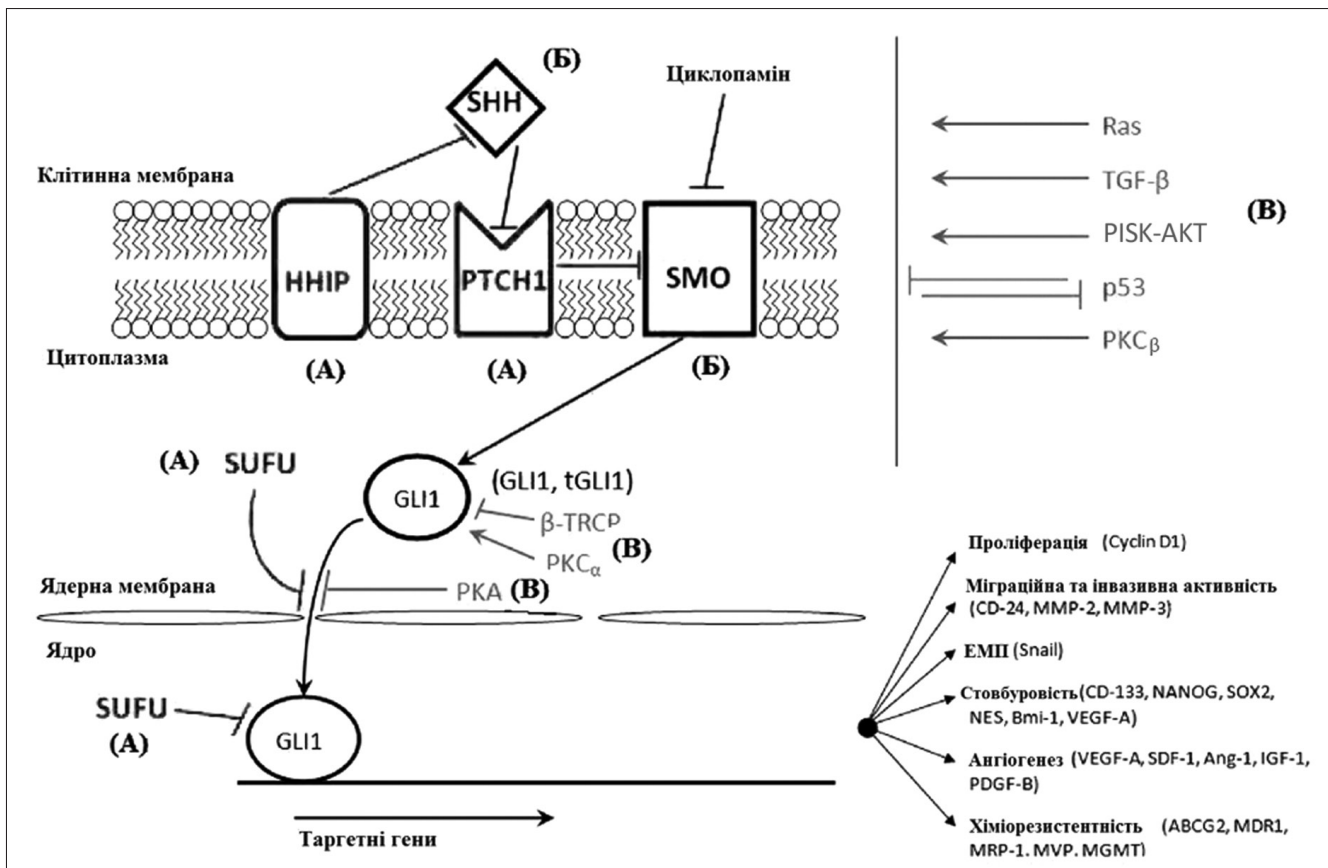

Рисунок. Схела функціонування основних колпонентів сигнального шляху Hedgehog [4]

Примітка. Літерою (А) позначені фактори, що перешкоджають ефекту сигнального шляху; (Б) активатори сигнального шляху; (В) - з'єднання інших сигнальних шляхів, що беруть участь у регуляиї̈ шляху $H H ; \rightarrow-$ активуючий вплив; $\perp_{-}$інгібуючий вплив; SHH - поліпептид Sonic Hedgehog; PTCH1 - рецептороподібний семиспіральний трансмембранний білок; SMO - 12-спіральний трансмембранний білок; HНIP - глікопротеїн, ендогенний антагоніст SHH; SUFU - негативний регулятор шляху HН (гальмування взаємодї GLI з генами); GLI - фактори транскрипиї̈; $\beta$-TRCP -

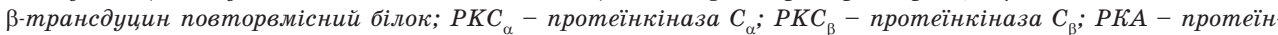
кіназа A; Ras - ГTФаза; TGF- $\beta$ - трансформуючий ростовий фактор $\beta$; PISK-AKT - сигнальний шлях; p53 (білок р53) - транскрипційний фактор, регулюючий клітинний иикл; Cyclin D1 - ииклін D1, білок з сімейства ииклінів, специфічно регулює фазовий перехід $G 1 / S$ у клітинному ииклі;

CD24 - передавач сигналу CD24, глікопротеїн; МMP-2 - матриксна металопротеїназа 2; МMP3 матриксна металопротеїназа 3; MGMT - метилтрансфераза; CD133 - промінін-1; NANOG - тран скрипиійний фактор; SOX2 - активатор білків розвитку фосфопротеїнів; NES - білок розвитку нейрогенезу; ВMI1 - протоонкоген, регуляція транскрипиї̈; VEGFA - судинний ендотеліальний фактор росту; Ang -1 - білок розвитку, задіяний в ангіогенезі та диферениіації клітин; IGF1 - інсуліноподібний фактор росту 1; PDGF-B - тромбоцитарний фактор росту B; MRP1 - білок, зв'язаний з множинною стійкістю до ліків; МGMT - О-6-метилгуанін ДНК метилтрансфераза. 
Крім ракових захворювань, що містять мутації, активація шляху НН може існувати в автокринному режимі. Це стосується низки форм раку людини (легенів, передміхурової залози, гліоми, меланоми, товстої кишки) [13-15]. Зареєстровано також лігандоопосередковану паракринну сигналізацію $[15,16]$.

У цілому, активована сигналізація НН-шляху 3 режимом передачі мітогенних сигналів (мутаційний, паракринний, автокринний) проявляється в гіперекспресії основних ланок передачі мітогенних сигналів за пухлинного росту [15-18], що зумовлює підходи до пошуку засобів лікування хворих на злоякісні новоутворення.

Натепер виявлено понад 200 сполук, що можуть впливати на сигнальний шлях НН як антагоністи [16]. Серед речовин, що проходять клінічні випробування, виділяють 3 типи інгібування шляху SHH [16]:

- інгібування поліпептиду SHH за допомогою антитіл і хімічних сполук, наприклад, роботнікініном;

- інгібування рецептора SMO за допомогою циклопаміну та його похідних, а також синтетичних сполук (вісмодегіб, сонідегіб та ін.);

- інгібування транскрипційних факторів GLI за допомогою сполук GANT56, GANT-61, HPI-1, HPI-2, HPI-3, HPI-4 та ін.

Сполуки, що відповідають зазначеним підходам, спрямовані на пригнічення активності молекул, які в цьому шляху детермінують злоякісний ріст. 3 рецептором НH взаємодіють антитіла до НН. Роботнікінін названий на честь доктора Айво Роботніка [3].

У розробці малих молекул, які специфічно інгібують сигнальний шлях $\mathrm{HH}$, увага спочатку зосереджувалася переважно на SMO. Найвивченішим інгібітором SMO є циклопамін [19], що зустрічається в природі в лілії Veratrum califormicum. Це стероїдний алкалоїд, що блокує трансмембранний білок SMO. Сполука продемонструвала високу ефективність за базально-клітинної епітеліоми, медулобластоми та інших форм злоякісного росту, але не пройшла клінічну розробку через неналежні фармакокінетичні характеристи- ки (нерозчинність у воді, неналежна стабільність, висока токсичність) [19, 20]. Але нові ефекти циклопаміну, які не досягалися раніше, а саме здатність викликати диференціювання пухлинних клітин та апоптоз не за генотоксичним механізмом сприяли широкому пошуку похідних циклопаміну з аналогічними йому характеристиками зв'язування та біологічними/терапевтичними властивостями. Деякі його полімери були схвалені FDA для клінічного застосування [20]. Ефективність циклопаміну щодо зв'язування з рецептором SMO, інгібіція активованого шляху $\mathrm{SHH}$ обумовили пошук синтетичних $\mathrm{HH}$ - сигнальних антагоністів.

У січні 2012 року FDA був схвалений Вісмодегіб для лікування дорослих 3 місцево поширеним або метастатичним базально-клітинним раком шкіри [21], у 2015 році - інший інгібітор SMO Сонідегіб (локально задавнений базально-клітинний рак) [22]. Значні клінічні результати були отримані в разі застосування Саридегібу [4].

Проводяться клінічні дослідження щодо поширення клінічних показань відомих препаратів [23]. Показано, що системний протигрибковий препарат ітраконізол є ефективним антагоністом SMO, що гальмує активність НН-шляху в усіх відомих мутаціях SMO, стійких до ліків [24]. Висока активність відмічена у вітаміну Д [24].

Дотепер пошук інгібіторів SMO був провідним. На жаль, уже спостерігається резистентність до них у пацієнтів з ВСС [19]. Це зумовило поширення досліджень на інші ланки сигнального шляху НH, на рівні факторів транскрипції GLI [25], їхне інгібування прямим зв'язуванням інгібіторів з білками GLI.

Білки GLI належать до сімейства білків zinc fingers, що є одним з найважливіших сімейств ДНК-зв'язуючих білків. Білок GLI складається з п'яти білків zinc fingers, 3 яких тільки палець 1 не контактує з ДНК. Цинкові пальці від 2 до 5 пов'язують основний паз і обертають спіраль ДНК. Вважається, що цинкові пальці 2 і 3 в основному зв'язують ДНК, тоді як пальці 4 і 5 безпосередньо контактують з парами основ ДНК [26, 27]. 
Як було зазначено, ген GLI був названий на честь гліома-асоційованого гомолога GLI1 [28]. Сьогодні надекспресію GLI1 описано в багатьох інших типах пухлин: медулобластомі [30], рабдоміосаркомі [31, 32], пухлинах простати [33, 34], біліарних пухлинах [35], пухлинах молочної залози [3638], пухлинах легенів [39], товстої кишки [40, 41] і сечового міхура [42].

Першими малими молекулами-інгібіторами сигналізації НH на рівні факторів транскрипції GLI були ідентифіковані GANT58 і GANT61. Було показано, що GANT61 безпосередньо зв'язує GLI1 [29]. Подальше вивчення сполуки проведено на численних типах раку, включаючи рабдоміосаркому, нейробластому, лейкемію, рак товстої кишки, підшлункової залози, шийки матки, шлунка. $\mathrm{IC}_{50}$ цієї сполуки була в діапазоні 5-15 мкмоль/л [19]. Висока їі ефективність передбачає перспективу використання в лікуванні злоякісних новоутворень людини.

Описано низку інших сполук, що ефективно інгібують як GLI1, так i GLI2 - опосередковану транскрипцію: зерумбон, арциріафлавін С, фізалін В, фізалін F [42], а також НPII-4, АTO, GlaB, GoI та BET [4, 43], що підкреслює ефективність націлення на фактори транскрипції GLI.

Слід звернути увагу на можливість неканонічної активації факторів транскрипції GLI кількома важливими сигнальними шляхами (MAPK, PISK, $\mathrm{TGF}_{\beta}$, Wnt, NF-kB та ін.), інгібітори яких можуть бути корисними в комплексному лікуванні пухлинної хвороби [19, 44-47].

Сьогодні все частіше розглядаються питання пухлинних стовбурових клітин (СОК) [48]. Вважається, що такі клітини контролюють розвиток пухлин, мають обмежену властивість до поділу, $€$ найхіміорезистентнішими [48, 49]. При цьому сигнальний шлях SHH контролює поділ дорослих стовбурових клітин, бере участь у розвитку багатьох видів раку [5, 50].

У 2006 році на з'їзді Американської Асоціації Досліджень Раку СОК були офіційно означені як клітини, здатні до самооновлення та створення гетероген- ної популяції клітин, що формують пухлину [51].

Усе більше даних свідчать про те, що саме СОК відповідають за метастазування, розвиток резистентності, пригнічення імунної відповіді та ін. [5, 16, 52]. Це ставить питання щодо нових підходів до таргетної терапії, спрямованої на СОК [51]. У цьому разі регресія пухлин і терміни ремісії після лікування залежать від знищення цієї дуже важливої частини клітин [53].

Велика кількість дослідних груп приділяе увагу пошуку препаратів проти СОК, які знаходяться на стадії доклінічних і клінічних випробувань, однак досі не відомо, коли СОК-спрямована терапія ввійде в стандартні протоколи лікування пацієнтів з онкологічними захворюваннями. Однак існуе низка успішних методів для пошуку препаратів, специфічних до СОК. Це скринінг бібліотек існуючих препаратів на СОК. У 2009 році Р. В. Gupta та співавт. протестували ефективність приблизно 16000 препаратів i біоактивних молекул на популяції стовбурових клітин молочної залози. Тільки 32 препарати показали селективну активність, і тільки саліноміцин був ефективним відносно СОК 3 резистентністю до хіміотерапії. Цей ефект був у 100 разів вищий, ніж у паклітокселу [54]. Відмічена активність сполуки DECA-14 і рапаміцину щодо СОК нейробластоми [57]. Багатообіцяючим методом $€$ використання онколітичних вірусів та імунотерапії $[55,56]$.

Розвиток гіпотези СОК сьогодні проходить згідно з рівнем існуючих знань поряд з пошуком таргетних препаратів, що гальмують передачу мітогенних сигналів на геном, у тому числі щодо сигнального шляху $\mathrm{HH}, 3$ раціональним використанням традиційних цитостатиків, що впливають на пухлинні клітини в стані мітотичного поділу.

Слід відмітити, що існуючі препарати, які гальмують сигнальний шлях НН, в Україні не зареєстровані та недоступні хворим через їхню високу вартість. Можна сподіватися на можливість таких досліджень на основі високого наукового та технологічного потенціалу нашої країни та необхідної уваги до стану лікування онкологічних хворих. 
1. Weinberg R. A. The biology of cancer - New York. Garland Science, 2007, 796 p.

2. Hanahan D., Weinberg R. A. The hallmarks of cancer. Cell. 2000. V. 1000, № 1. 424 p.

3. Влияние сигнального пути Hedgehog на химиорезистентность низкодифференцированных глиом. С. А. Черепанов, Н. Ф. Гриненко, О. М. Антонова и др. Бюллетень экспериментальной биологии и медицины. 2017, Т. 164, № 9. С. 341-346.

4. Hedgehog Signaling: From Basic Biology to Cancer Therapy. F. Wu, Y. Zhang, B. Sun et al. Cell Chemical Biolog. 2017. V. 24. P. 252-280.

5. Activation of the hedgehog signaling pathway in human cancer. Yang, G. Xie, Q. Fan, J. Xie. Oncogene. 2010. V. 29. P. 469-481.

6. Ingham D. W., McMahon A. P. Hedgehog signaling in animal development: paradigms and principles. Genes Dev. 2001. V.15. P. 3059-3087.

7. Almawash S. A., Mondal G., Mahato R. I. Coadminicastration. Polimeric Conjugates Docetaxcel and Cyclopamine. Synergistielly Inhibits orthotopic Pancreatic. Cancer Growth and Metastases. Pharm. Res. V. 35 (1). 17dub. 10.100 67/5 1195-017-200-33. Pharm Res. Author manuscript; available in PMC. 2018, V. 12. P. 21.

8. Granulation tissue masquerading as basic cell carcinoma after treatment with Vismodehib. J. Miedema, M. O. Meyers, D. Zene et al. Medical Scienes Bidg. J. http//dx.dol.org/ 10.10.16161 y der 2017.07.025.

9. Sonic hedgehog controls stem cell behavior in the postnatal and aduet brain. V. Palma, D. A. Lim, N. Dahmane et al. Development. 2005. V. 132. P. 335-344.

10. Targeting hedgehog signaling in cancer research and clinical developments. J. Xie, C. M. Bartels, S. W. Barton, G. Dongsheng. OncoTargets and Therapy. 2016. V. 6. P. 1425-1435.

11. Missense mutations in $\mathrm{SMOH}$ in sporadic lashe cell carcinomas of the skocn and primitive neuroectodermal tumors of the central nervous system. J. Keitfenberger, M. Wolter, R. G. Weber et al. Cancer Res. 1998. V. 58. P. 1798-1803.

12. Sporadic meduloblastomas conteit PTCH mutations. C. Raffel, R. B. Jenckins, L. Frederick et al. Cancer Res. 1997. V. 57. P. 842-845.

13. Мингалеева Р. Н., Мифтахова Р. Р., Ризванов А. А. Стволовые опухолевые клетки: 20 лет позади. Гены и Клетки. 2015. Т. 10, № 2. С. 11-15.

14. Hitzenlerger M., Schuster D., Hofer T. S. The Binding Model oh the Sonic Hedgehog Inhibitor Robotnikinin, a combined Docking and QM/MMMD Study. Frontiers in Chemistry. 2017. V. 5. P. 1-14.

15. March A., Matsub W. Targeting Hedgehog Cancer Stem Cell Pathway. Clin. Cancer Res. 2010. V. 11 (12). P. 3130-3140.

16. Hedgehog - сигналинг и его роль в патогенезе нейроонкологических заболеваний. С. А. Черепанов., В. П. Баклушов, А. Н. Габашвили и др. Биомедицинская химия. 2015. Т. 61. Вып. 3. C. 332-342.

17. Meduloblastoma: clinicopathological Correlates alSHH, Wnt, and non-SHH/Wnt Molecular Subgroups. D. W. Ellison, J. Dalton, M. Kotek et al. Acta Newropathol. 2011. V. 121. P. 381-396.

18. Activations of the hedgehog-signaling pathway in human cancer and the clinical implications. L. Yang, G. Xie, Q. Fam, J. Xie. Oncogene. 2010. V. 29 (4). P. 469-481.

19. Gannisscon, Isebaert S., Hausermans K. Targeting the Hedgehog sidnaling pathway in cancer: beyond Smoothened. Oncotarget. 2015. V. 6, № 16. P. 13899-13913.

20. Combination therapy with Micellarized cyclopamint and temozolamide attenuate glioblastome growth through Gli1 down-regulation. Y.-J. Liu, Y.-C. Ma, W.-J. Zhang et al. Oncotarget. 2017. V. 8 (26). P. 42495-42509.

21. In vitro and in vivo inhibition of breast cancer cell growth by targeting Hedgehog/Gli pathway with Smu (GDC - 0449) or GLI (Gant - 61) inhibitors. M. Benvenuto, L. Masuelli, E. De Smaele et al. Oncotarget. 2016. V. 7, № 8. P. 9220-9270.

22. Bumess C. B. Sonidegib: first global approval. Drugs. 2015. V. 75. P. 1559-1566.

23. Abstract A-55: a first in human, phase 1 study of an hedgehog pathway antagonist, BMS833923(XL. 139), in subjects with advanced or metastatic solid tumors Mol. L. L. Siu, K. P. Papadopoulos, S. R. Alkerts. et al. Cancer Ther. 2009. P. 8-55.

24. Intraconazole and arsenic trioxide inhibitor hedgehog pathway activation and tumor growth associated with acquired resistance to smoothened antagonists. J. Kim, B. T. Attab, J. Y. Tang et al. Cancer Cel. 2013. V. 23. P. 23-34.

25. GLI/DNA interaction is a druggable target for Hedgehog-dependent tumors. P. Infante, M. Mori, R. Alfonsi et al. The EMBO Journal. 2015. V. 34, № 2. P. 200-217.

26. Pavletich N. P., Pabo C. O. Crystal structure of a fife-finger GLI - DNA complex: new perspectives on zinc fingers. Science. 1993. V. 261. P. 1701-1707.

27. Kinzler K. W., Vogelstein B. The GLI gene encodes a nuclear protein which binds specific sequences in the human oncotaget Gerome. Mol. Cell Biol. 1990. V. 10. P. 631-642.

28. Smoothened mutation confers resistance to a Hedgehog pathway inhibitor in medulloblastoma. R. L. Yauch, G. J. Digkgraaf, B. Alicke. Science. 2009. V. 326. P. 572-574.

29. Genomics identifies medulloblastoma subgroups that are enriched for specific genetic alterations. M. C. Thompson, C. Fuller, T. L. Hogg et al. J. Clin Oncol. 2006. V. 24. P. 1924-1931. 
30. Activation of the hedgehog pathway confers a poor prognosis in embryonal and fusion gene - negative alveolar rhabdomyosarcoma. A. Zibat, E. Missiaglia, A. Rosenberger et al. Oncogene. 2010. V. 29. P. 6323-6330.

31. Deregulation of the hedgehog signalling pathway: a possible role for the PTCH and SUFU genes in human rhabdomyoma and rhabdomyosarcoma development. U. Tostar, C. J. Malm, J. M. MeisKindblom et al. J. Pathol. 2006. V. 208. P. 17-25.

32. Hedgehog signaling in prostate regeneration, neoplasia and metastasis. S. S. Karhadkar, G. S. Bova, N. Abdallah et al. Nature. 2004. V. 431. P. 707-712.

33. Khatra H., Bose C., Sinha S. Discovery of Hedgehog antagonists for cancer therapy. Curr. Med. Chem. 2017. V. 24. P. 2033-2058.

34. Hedgehog signaling protein expression and its association with prognostic parameters in prostate cancer: a retrospective study from the view point of new 2010 anatomic stage/ prognostic groups T. J. Kim, J. Y. Lee, T. K. Hwang et al. J Surg Oncol. 2011. V. 104. P. 472-479.

35. Activated hedgehog pathway is a potential target for pharmacological intervention in biliary tract cancer. T. Kiesslich, C. Mayr, J. Wachter et al. Mol Cell Biochem. 2014. V. 396. P. 257-68.

36. Hedgehog signaling pathwayis a new therapeutic target for patients with breast cancer. M. Kubo, M. Nakamura, A. Tasaki et al. Cancer Res. 2004. V. 64. P. 6071-6074.

37. Expression of the glioma-associated oncogene homolog (GLI)1 in human breast cancer is associated with unfavourable overall survival. H. A. Ten, N. Bektas, Von S. S. et al. BMC Cancer. 2009. V. 9. P. 298.

38. Hedgehog signaling pathway mediates the progression of non-invasive breast cancer to invasive breast cancer. M. Souzaki, M. Kubo, M. Kai et al. Cancer Sci. 2011. V. 102. P. 373-381.

39. Activation of hedgehog signaling pathway in human non-small cell lung cancers. Z. Hong, A. Bi, D. Chen et al. Pathol Oncol Res. 2014. V. 20 (4). P. 917-922.

40. Prognostic value of hedgehog signaling pathway in patients with colon cancer. M. Xu, X. Li, T. Liu et al. Med Oncol. 2012. V. 29. P. 1010-1016.

41. Human colon cancer epithelial cells harbour active signalling that is essential for tumour growth, recurrence, metastasis and stem cell survival and expansion. F. Varnat, A. Duquet, M. Malerba et al. EMBO Mol Med. 2009. V. 1. P. 338-351.

42. Naturally occurring small-molecule inhibitors of hedgehog/GLI-mediated transcription. T. Hosoya, M. A. Arai, T. Koyano et al. Chembiochem. 2008. V. 9. P. 1082-1092.

43. Dual degradation signals control Gli protein stability and tumor formation. E. G. Huntzicker, I. S. Estay, H. Zhen et al. Genes Dev. 2006. V. 20. P. 276-281.

44. Stecca B., Ruiz I. A. Context-dependent regulation of the GLI code in cancer by HEDGEHOG and non-hedgehog signals. J Mol Cell Biol. 2010. V. 2. P. 84-95.

45. Onishi $H$., Katano $M$. Hedgehog signaling pathway as a therapeutic target in various types of cancer. Cancer Sci. 2011. V. 102. P. 1756-1760.

46. Aberger F., Ruiz I. A. Context-dependent signal integration by the GLI code: the oncogenic load, pathways, modifiers and implications for cancer therapy. Semin. Cell Dev Biol. 2014. V. 33. P. 93-104.

47. Lauth M., Toftgard R. Non-canonical activation of GLI transcription factors: implications for targeted anti-cancer therapy. Cell Cycle. 2007. V. 6. P. 2458-2463.

48. Amerchant A., Motsui W. Targeting Hedgehog - a cancer stem cell pathway. Clin.Cancer Res. 2010. V.16 (12). P. 3130-3140.

49. Стволовые клетки при острых миелоидных лейкозах. Д. Ф. Глузман, Л. М. Скляренко, Т. С. Иванивская и др. Онкология. 2018. Т. 20, № 1. С. 4-9.

50. Hedgehog Signaling in the Maintenance of the Cancer Stem Cells. C. R. Cochrane, A. Szczepay, D. N. Watkins, J. E. Cain. Cancer. 2015. V. 7. P. 1554-1585. https://doi.org/10.3390/cancers 7030851.

51. Cancer stem cells-perspectives on current status and future directions: AACR Workshop on cancer stem cells. M. F. Clarke, J. F. Dick, P. B. Dirks et al. Cancer Res. 2006. V. 66 (19). P. 9339-44.

52. Cancer stem cells and their role in metastasis. Y. Shiozawa, B. Nie, K. J. Pienta et al. Pharmacology\&Therapeutics. 2013. V. 138 (2). P. 285-93.

53. Вартанян А. А., Барышников К. А. Терапия, направленная на стволовую клетку опухоли: надежды и возможности. Российский биотерапевтический журнал. 2016. Т. 15. С. 8-17.

54. Adoptive transfer of syngeneic T-cells transduced with a chimeric antigen receptor that recognizes murine CD 19 can eradicate lymphoma and normal B cells. J. N. Kochenderfer, Z. Yu, D. Frasneri et al. Blood. 2010. V. 116 (19). P. 3875-86.

55. Trial watch: oncolytic viruses for cancer therapy. J. Pol, N. Bloy, F. Obrist et al. Oncoimmnunology. 2014. V. 3. P. e28694.

56. Antiviral and antitumor T-cell immunity in patients treated with GM-CSF-coding oncolytic adenovirus. A. Kanerva, P. Nokisalmi, J. Diaconu et al. Clin. Cancer Res. 2013. V. 19 (10). P. 2734-44.

57. Selective targeting of neuroblastoma tumor-initiating cells by compounds identified in stem cellbased small molecule screens. K. M. Smith, A. Datti, M. Fujitani et al. EMBO Mol. Med. 2010. V. 2 (9). P. 371-84.

58. Pharmacodynamic and pharmacokinetic neoadjuvant study of hedgehog pathway inhibitor Sonidegib (LDE-225) in men with high-risk localized prostate cancer undergoing prostatectomy. A. E. Ross, R. M. Hughes, S. Glavaris et al. Oncotarget. 2017. V. 8, № 61. P. $104182-104192$. 


\section{Н. І. Шарикіна, А. Г. Радівоєвич, М. А. Мунько, С. В. Максюта, Т. А. Бухтіарова Сигнальний шлях Hedgehog: від механізмів трансдукції до пошуку протипухлинних засобів}

У статті наведено огляд сучасних даних щодо клітинного сигнального шляху Hedgehog, у тому числі за пухлинного росту. Розглянуті основні ланки трансдукції мітогенних сигналів як мішеней для пошуку протипухлинних засобів. Відмічено перші успіхи в цьому напрямі: препарати - Вісмодегіб, Сонідегіб та біологічно активні речовини - GANT 58, GANT 61 та ін., активні за деяких форм злоякісних новоутворень людини.

Ключові слова: сигнальний шлях Hedgehog, ланки трансдукції, злоякісні новоутворення, протипухлинні засоби

\section{Н. И. Шарыкина, А. Г. Радивоевич, М. А. Мунько, С. В. Максюта, Т. А. Бухтиарова Сигнальний путь Hedgehog: от механизмов трансдукции к поиску противоопухолевых средств}

В статье представлен обзор современных данных по клеточному сигнальному пути Hedgehog, в том числе при опухолевом росте. Рассмотрены основные звенья трансдукции митогенных сигналов в качестве мишеней для поиска противоопухолевых средств. Отмечены первые успехи в этом направлении: препараты Висмодегиб, Сонидегиб и биологически активные вещества - GANT 58, GANT 61 и др., активные при ряде форм злокачественных новообразований человека.

Ключевые слова: сигнальный путь Hedgehog, звенья трансдукции, злокачественные новообразования, противоопухолевые средства

\section{N. I. Sharykina, A. G. Radivoevych, M. A. Munko, S. V. Maksiuta, T. A. Bukhtiarova The Hedgehog signaling pathway: from mechanisms of transduction to the research of antitumor drugs}

The article provides an overview of contemporary data dealing with the Hedgehog signaling pathway, including at the malignant growth. There were also considered the main links of mitogenic signals transduction as the targets for searching of antitumor drugs. The first successes in this direction were noted, namely drugs and substances with antitumor activity (Wismodegib, Sonidegib, GANT 58, GANT 61 et al.)

Key words: Hedgehog signaling pathway, links of mitogenic signals transduction, malignant growth, antitumor drugs

Надійшла: 10 травня 2019 р.

Прийнята до друку: 23 травня 2019 р.

Контактна особа: Шарикіна Надія Іванівна, доктор медичних наук, професор, лабораторія онкофармакології, дУ «Інститут фармакології та токсикології НАМНУ», буд. 14, вул. Антона Цедіка, м. Київ, 03057. Тел.: + 380444568322. 